\title{
RANCANGAN PEMBELAJARAN TEACHING FACTORY DI SMK TATA BUSANA
}

\author{
Noor Fitrihana \\ Universitas Negeri Yogyakarta, Kampus Karangmalang Yogyakarta Indonesia \\ E-mail: noor_fitrihana@uny.ac.id
}

\begin{abstract}
ABSTRAK
Peraturan Pemerintah Republik Indonesia Nomor 41 Tahun 2015 tentang pembangunan sumber daya industri menyatakan bahwa penyelenggaraan pendidikan vokasi industri berbasis kompetensi harus dilengkapi dengan Lembaga Sertifikasi Profesi (LSP), pabrik dalam sekolah (teaching factory), dan tempat uji kompetensi (TUK). Peraturan Menteri Pendidikan dan Kebudayaan Nomor 22 tahun 2016 tentang standar proses pendidikan dasar dan menengah menyatakan bahwa salah satu model pembelajaran yang perlu dikembangkan adalah pembelajaran yang menghasilkan karya berbasis pemecahan masalah (project based learning) disesuaikan dengan karakteristik kompetensi dan jenjang pendidikan. Kedua peraturan ini menjadi landasan implementasi teaching factory (TEFA) di sekolah menengah kejuruan (SMK). Makalah ini selanjutnya akan membahas tentang rancangan pembelajaran TEFA di SMK kompetensi keahlian Tata Busana
\end{abstract}

\section{PENDAHULUAN}

Proses pembelajaran konvensional di pendidikan vokasi saat ini dirasa kurang optimal sehingga diperlukan pendekatan baru dalam proses pembelajaran untuk menghadapi perkembangan dunia usaha dan industri ke depan yaitu:

a. Memungkinkan pelatihan dalam lingkungan manufaktur yang nyata

b. Modernisasi proses belajar dan membawanya lebih dekat dengan kondisi industri yang nyata

c. Memanfaatkan proses dan teknologi di industri secara langsung untuk adopsi pengetahuan dan teknologi dalam proses manufaktur.

d. Mendorong inovasi di bidang manufaktur dengan memperbaiki kemampuan pekerja, misalnya kemampuan penyelesaian masalah , kreativitas atau kemampuan berpikir sistem, calon pekerja yang memiliki kemampuan inovasi adalah pendorong utama daya saing manufaktur. ( Eberhard Abele dkk, 2015).

Untuk mengantisipasi kebutuhan tenaga kerja di masa depan maka tuntutan pembelajaran di SMK saat ini adalah :

a. Menghasilkan karya produk kreatif yang layak jual. b. Menumbuhkan wirausaha dengan secara hands on dan learning by doing (praktek langsung).

c. Menggabungkan interaksi digital dan konvensional.

d. Menggunakan pendekatan saintifik, inquiri, discovery, problem nyata , proyek, produksi dan TEFA.

e. Pencapaian Kompetensi yang diakui dengan sertifikasi profesi.

f. Menumbuhkan keterampilan abad 21 .

g. Penguatan pendidikan karakter dan budaya industri

Untuk mengakomodasi berbagai tuntutan dunia usaha dan industri aga SMK rmenghasilkan lulusan yang kompeten tidak hanya link and match namun juga Plug and Play maka dikembangkan pembelajaran Teaching Factory . Teaching Factory (TEFA) adalah pembelajaran yang menghadirkan suasana yang mendekati lingkungan dan aktifitas industri sesungguhnya melalui kerjasama dengan industri dengan pembelajaran berbasis produk untuk menghasilkan lulusan yang kompeten, berkarakter berbudaya kerja dan berjiwa wirausaha melalui kegiatan produksi baik berupa barang atau jasa yang memiliki standar perencanaan, prosedur dan pengendalian kualitas industri dan layak dipasarkan ke konsumen/masyarakat 
(Fitrihana, N., 2017). Pembelajaran TEFA merupakan salah satu pendekatan pembelajaran yang sesuai dengan tuntutan kompetensi saat ini dan masa depan. Dewasa ini implementasi pembelajaran berbasis industri kembali meningkat dan banyak dipraktekkan di banyak negara untuk tujuan pendidikan, pelatihan maupun penelitian.

Perkembangan konsep TEFA yang mengarah pada gabungan pemahaman tentang TEFA dalam pengertian yang sempit dan TEFA dalam pengertian yang lebih luas. Konsep TEFA dapat diimplementasikan dalam banyak hal/cara yang berbeda guna mencapai kompetensi yang diharapkan. Konsep TEFA dalam arti sempit adalah memberikan pengalaman nyata pada lingkungan fisik sistem rantai nilai produk dimana para peserta didik bisa melakukan, mengevaluasi, dan merefleksikan hasil pekerjaannya sendiri. Sedangkan dalam pengertian yang lebih luas sesuai dengan perkembangan revolusi industri 4.0 maka TEFA tidak hanya dilakukan terbatas pada lingkungan fisik saja namun juga lingkungan virtual diantaranya adalah dengan cara :

a. Sistem rantai nilai tambah produk (lingkungan, proses dan teknologi) dapat ditampilkan secara virtual.

b. Interaksi dalam pembelajaran TEFA dapat dilakukan dengan memanfaatkan Teknologi komunikasi dan informasi (dalam jaringan)

c. Poduk yang dihasilkan berupa jasa/layanan

(Eberhard Abele dkk, 2015)

Pelaksanaan pembelajaran teaching factory tidak hanya dapat hanya dalam lingkungan fisik saja (luar jaringan) namun juga dapat dilakukan pembelajan dalam jaringan. Teaching factory dapat dilakukan dengan model kelas terbalik (Flipped Learning), Blended learning maupun adaptiv learning. Rekayasa lingkungan virtual menggunakan augmented and virtual reality (AR/VR) ataupun berbagai jenis simulasi digital lainnya. Kemajuan teknologi ini sangat membantu dalam menciptakan simulasi lingkung kerja yang nampak nyatapada peserta didik. Pada pembahasan selanjutnya akan difokuskan rancangan TEFA pada SMK Tata Busana.

\section{SMK TATA BUSANA}

Indonesia merupakan salah satu pemain utama dalam industri pakaian jadi di dunia. Indsutri fashion juga meruapakan salah satu sub sektor indsutri reatif sebagai penyumbang penyumbang terbesar pada produk domestik bruto nasional sebesar 18,15 \% (Bekraf, 2017). Industri tekstil dan garmen juga menjaid salah satu dari 5 sektor uatama yang diharapkan dapat berkembang untuk menghadapi tantangan revolusi industri 4.0 dalam program Making Indonesia 4.0 yang diluncurkn Presiden Jokowi pada tahun 2018 ini (Kemenperin, 2018) . Salah satu program prioritas dalam menghadapi tantangan revolusi indsutri 4,0 adalah meningkatkan kualitas sumber daya manusia. SMK Tata Busana dihrapkan mampu mendukung dan menyiapkan tenaga kerja yang kompeten untuk meningkatkan tumbuhnya industri fashion menghadapi era revolusi Industri 4.0. Ada sekitar 530 SMK Bidang Tata Busana dengan total siswa 47.205 di seluruh Indonesia seperti terlihat pada tabel 1. Potensi SDM yang cukup tinggi untuk mengembangkan industri fashion bersaing di tingkat global 
Tabel. 1. Jumlah Sekolah dan Siswa SMK Tata Busana

\begin{tabular}{ccc}
\hline SMK Tata Busana & Jumlah Sekolah & Jumlah Siswa \\
\hline SMK Negeri & 295 & 31959 \\
SMK Swasta & 235 & 15246 \\
Total & 530 & 47.205 \\
\hline
\end{tabular}

Sumber : (diolah dari Direktorat pembinaan SMK, 2016)

Salah satu komponen utama dalam pelaksanaan TEFA adalah adanya kerjasama dengan industri. Untuk mengembangkan kerjasama maka perlu mempertimbangkan ekosistem link and match antara sekolah. masyarakat dan dunia industri seperti terlihat pada gambar 1. Manajemen SMK Tata Busana harus mampu menjalin kerjasama dan berinteraksi degan para stakeholder untuk peningkatan kualitas pembelajaran.

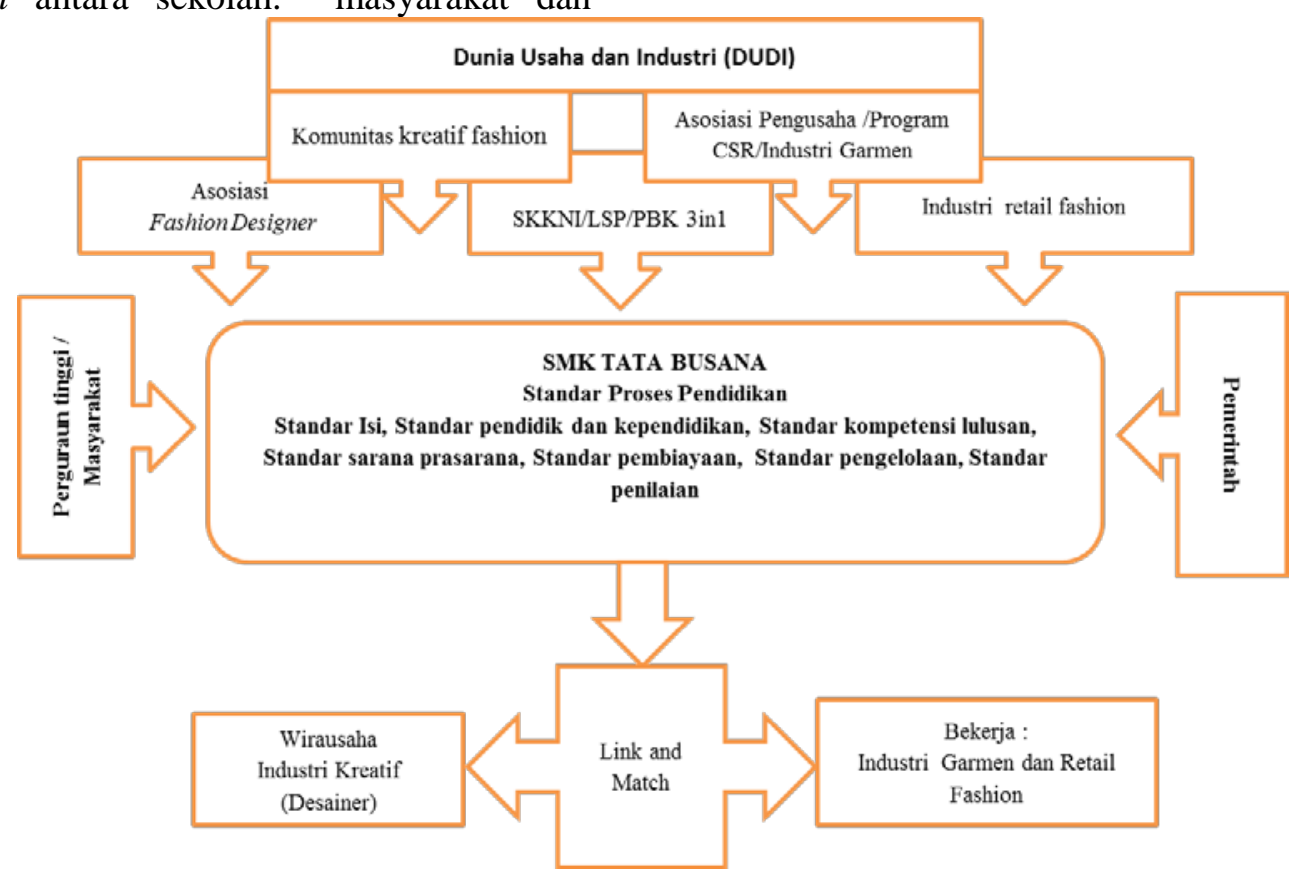

Gambar 1. Ekosistem link and Match SMK Tata Busana

\section{RANCANGAN PEMBELAJARAN TEFA DI SMK TATA BUSANA}

Ada 3 komponen yang perlu disiapkan untuk pelaksanan TEFA yaitu lingkungan kerja, produk dan proses pembelajaran .

1.1Penataan dan pembenahan lingkungan kerja/bengkel sesuai dengan di Industri.

Untuk melaksanan pembelajaran TEFA perlu dilakukan pembenahan dan penataan bengkel yang diatur sedemikian rupa sehingga menyerupai lingkungan kerja di industri. Tata letak mesin, area kerja, alur produksi, budaya kerja dan prosedur kerja mengadopsi dari industri. Industri mitra sangat penting dalam menciptakan susana kerja di industri. Dalam implementasi TEFA SMK Tata busana dapat bekerjasam dengan indsutri garmen maupun dengan asosiasi desainer. 


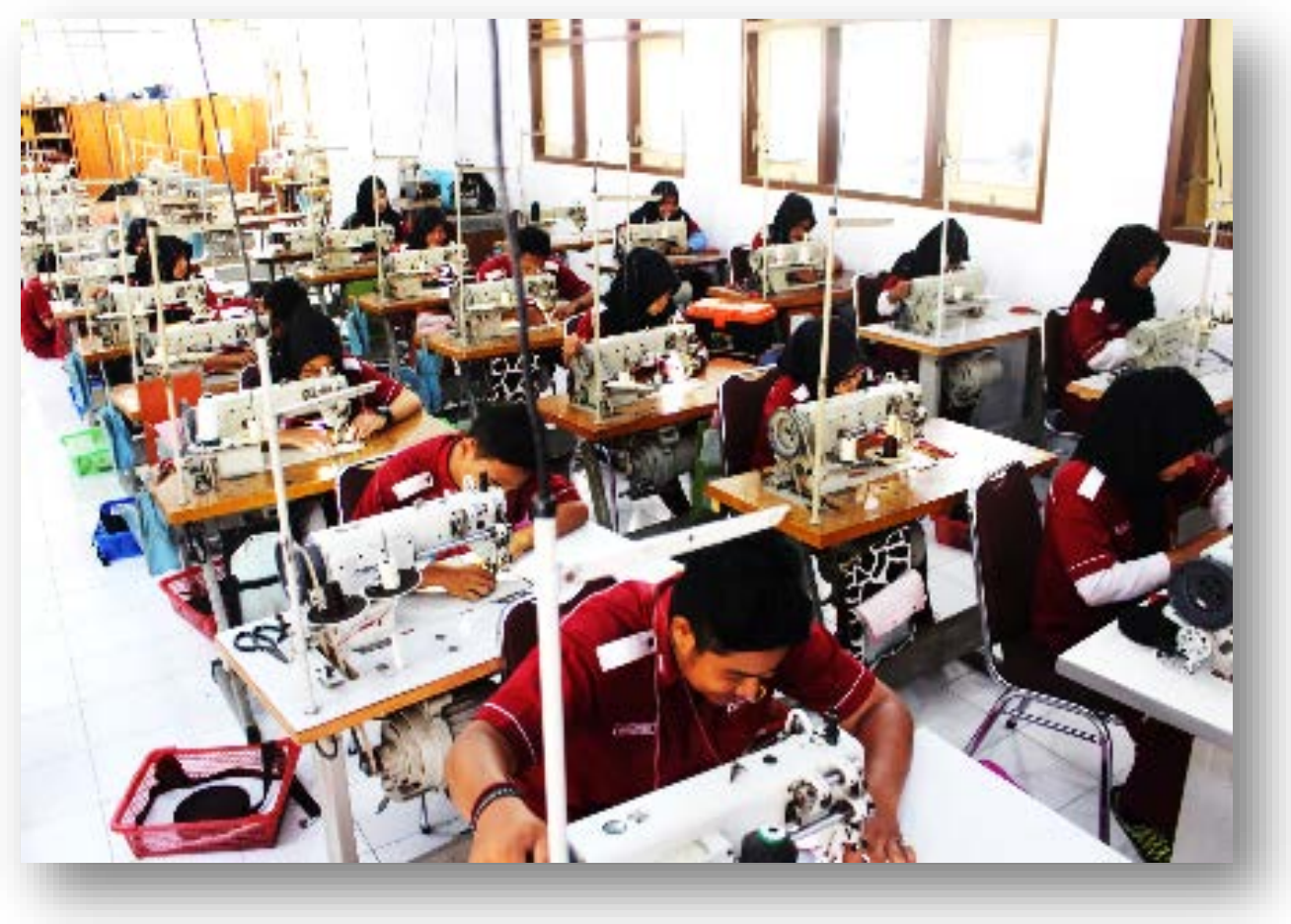

Gambar 2. Penataan Laboratorium Jahit seperti di industri garmen Sumber : Dokumentasi SMK N 1 Kalasan

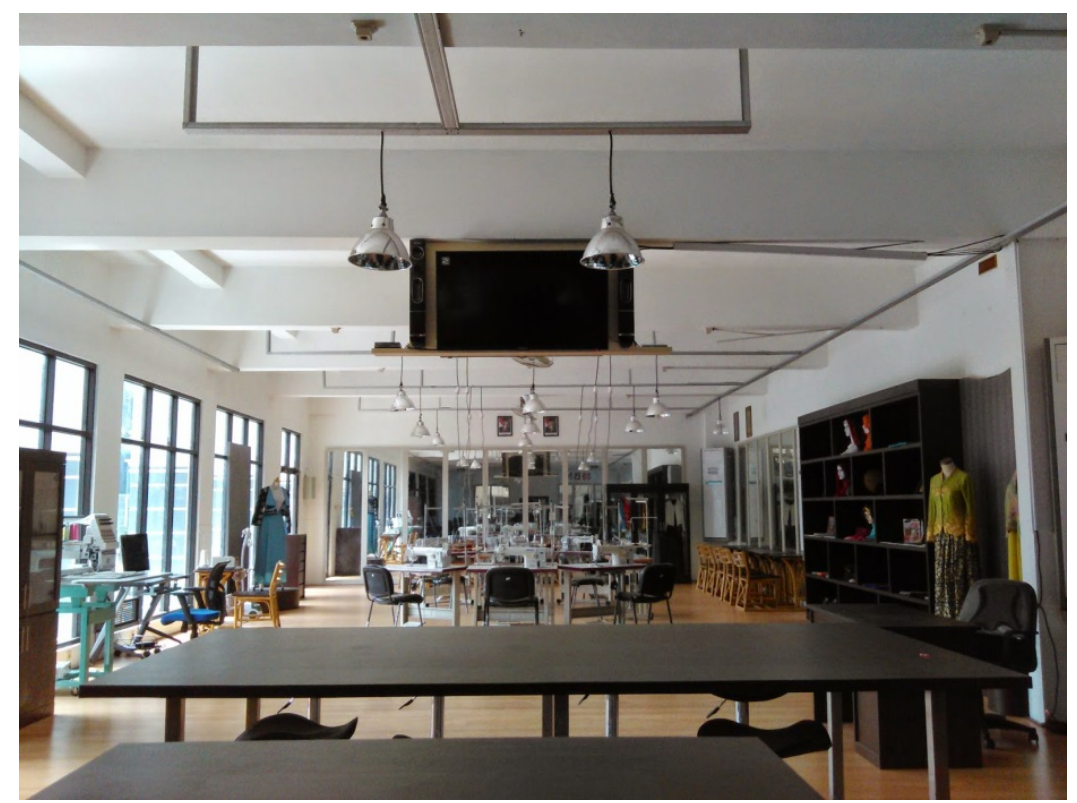

Gambar 3. Penataan Laboratorium Busana seperti studio fashion desainer Sumber : dokumentasi SMK NU Banat 
Gambar 2 menunjukkan suasana laboratorium di tata seperti kondisi lingkungan kerja di industri garmen dimana mengikuti alur produksi sistem ban berjalan untuk menghasilkan produk Sedangkan pada gambar 3 suasana laboratorium busana di tata seperti suasan di studio fashion Designer dimana dilengkapi berbagai referensi sumber ide, peralatan dengan teknologi terkini seperti bordir komputer, Pola komputer dan animasi

\section{PRODUK /JASA}

Produk/jasa dalam pembelajaran TEFA adalah sebagai media pengantar untuk mencapai suatu kompetensi tertentu, jadi bukan sekedar produk yang dihasilkan dari pemanfaatan sarana/prasarana yang ada. Untuk itu dalam menetapkan produk yang akan diproduksi harus mempertimbangkan jumlah kompetensi yang dapat diantarkan melalui produk tersebut dan standar kualitas dan nilai guna produk (dapat memenuhi kebutuhan internal atau eksternal).

Dalam konteks aktifitas industri untuk menghasilkan produk maka produk dapat didefinisikan segala sesuatu (barang ataupun jasa) dengan segala attributnya yang dapat ditawarkan ke pasar secara komersial untuk digunakan atau dikonsumsi oleh konsumen dalam rangka memenuhi keinginan dan kebutuhan konsumen sehingga memuaskan konsumen. Atribut produk yang dilihat
3D untuk busana. Dengan penataan laboratorium yang mencerminkan suasana lingkungan kerja di industri akan mengantarkan siswa untuk lebih mudah beradaptasi dengan lingkungan kerja di masa depan. SMK dapat memuaii dengan $m$ mengoptimalkan sumberdaya yang dimiliki untuk mengembangkan lingkungan kerja seperti di industri secara bertahap.

konsumen sebelum membeli sebuah produk diantaranya adalah brand/merk, kinerja, spesifikasi teknis, harga, desain, warna, daya tahan, pengalaman dan reputasi perusahaan sehingga menjadi totalitas bentuk dan karakteristik produk yang menunjukkan kemampuannya untuk memuaskan kebutuhan konsumen yang tampak jelas maupun tersembunyi. Kriteria produk yang dikembangkan/dipilih dalam pelaksanaan TEFA diantaranya adalah :

1) Mampu mengantarkan pencapaian kompetensi siswa

2) Memiliki potensi pasar yang baik untuk memenuhi kebutuhan internal maupun eksternal

3) Kemampuan produk untuk diproduksi dengan sumberdaya yang dimiliki

4) Dapat dikembangkan dan ditingkatkan secara berkelanjutan

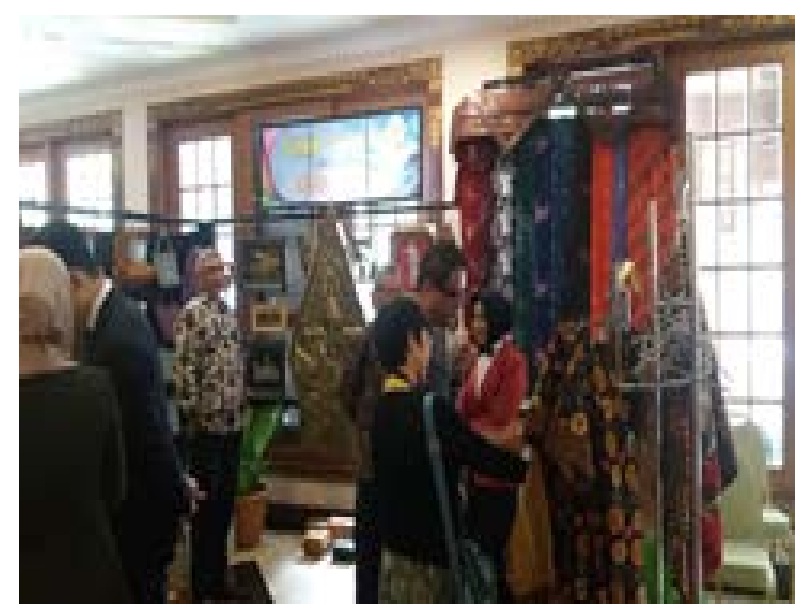

Gambar 4. Produk TEFA SMKN 1 Kalasan

Sumber : Dokumentasi penulis 


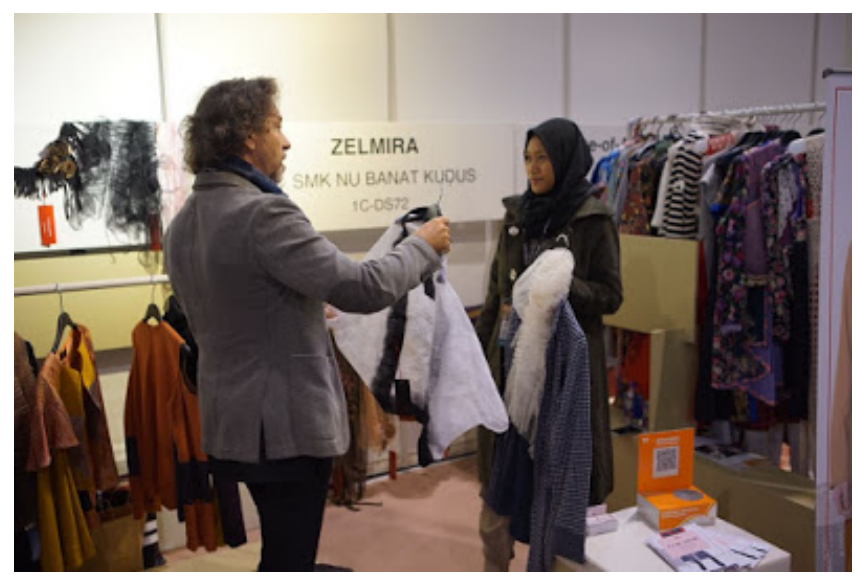

Gambar 4. Produk TEFA SMK NU Banat Sumber : Dokumentasi SMK NU Banat

\section{PEMBELAJARAN}

TEFA dapat dilakukan pada 1 mata pelajaran produktif danatau dengan kolaborasi beberapa mata pelajaran bahkan antar kompetensi keahlian akan sangat tergantung pada kompleksitas produk/proyek yang dikembangkan. Produk/jasa harus didasarkan pada pencapaian kompetensi yang diharapkan, kualifikasi guru, persyaratan kompetensi siswa dari mata pelajaran yang telah ditempuh, prospek bisnis/pasar, ketersediaan bahan baku dan peralatan yang dimiliki serta program kemitraan yang dikembangkan dengan industri. Kerangka dasar pembelajaran TEFA meliputi beberapa aspek berikut:

1) Profil karir dan atau peluang usaha terkait Mengidentifikasi profil karir lulusan sesuai capaian pembelajaran sesuai rdengan standar kompetensi. Untuk SMK Tata Busana misalnya

a) Bekerja di industri garmen

b) Wirausaha di sektor indsutri kreatif fashion

c) Mengidentifikasi standar kompetensi kerja nasional SKKNI dan uji kompetensi yang diperlukan,

Integrasi elemen kompetensi dalam dokumen SKKNI terkiat dalam proses pembelajaran merupatan tuntutan pembelajaran berbasis kompetensi untuk menguatkan link and match dengan dunia usaha dan inustri. SKKNI yang terkait dengan SMK tata busana diantaranya adalah:

a) SKKNI bidang merancang mode busana berdasarkan keputusan menteri tenaga kerja dan tranmigrasi nomer 116 tahun 2007

b) SKKNI bidang Menjahit pakaian berdasarkan keputusan menteri tenaga kerja dan transmigrasi nomer 92 tahun 2008

c) SKKNI bidang custome made busana wanita berdasarkan keputusan menteri tenaga kerja dan transmigrasi nomer 90 tahun 2010

d) SKKNI bidang desain busana berdasarkan keputusan menteri ketenaga kerjaan nomer 78 tahun 2014

e) SKKNI bidang produksi pakaian jadi masal berdasarkan keputusan menteri ketenagakerjaan nomer 305 tahun 2015

f) SKKNI bidang bordir berdasarkan keputusan menteri ketenagakerjaan nomer 377 tahun 2015

g) SKKNI bidang kewirausahaan industri berdasaran keputusan menteri ketenagakerjaan nomer 53 tahun 2014

2) Analisis Sumberdaya

SMK perlu membuat analisis kesenjangan dan potensi sumberdaya yang dimiliki untuk mencapai standar kompetensi lulusan. Berdasarkan analisis kesenjangan ini digunakan untuk merancang strategi pengembangan sekolah. Mengidentifikasi keterkaitan anatar Mata PelajaranMelalui analisis Kompetensi Inti dan kompetesi dasar pada mata pelajaran yang mendukung untuk pencapaian kompetensi dan melaksanakan produksi dalam TEFA. 
Implementasi TEFA dapat dikembangkan dalam 1 mata pelajaran maupun kolaborasi antar mata pelajaran.

3) Menetapkan produk TEFA

Untuk menetapkan produk yang akan diproduksi perlu dilakukan analisis kurikulum untuk produk/jasa yang dapat dihasilkan dari proses pembelajaran dan sumberdaya yang dimiliki. Produk yang dipilih ditetapkan berdasarkan analisis kebutuhan kompetensi yang akan dicapai, kebutuhan sumberdaya dan potensi pasar produk dan potensi pengembangnnya.

4) Melibatkan dan mengembangkan kerjasama dengan industri mitra

Pengembangan kerjasama sangat diperlukan dalm pelaksanaan TEFA. Bentuk kerjasama TEFA diantara nya dapat berupa dukungan sumberdaya, budaya industri, pengembangan perangkat pembelajaran, magang, pengaturan tata letak, pengembangan dan pemasaran produk, uji kompetensi, guru tamu dan lainnya.

5) Peningkatan kompetensi/pengalaman guru pelatihan/magang jika diperlukan

Guru merupakan ujung tombak dalam pelaksanaan pembelajaran. Untuk dalam pelaksanan TEFA diperlukan guru yang memiliki pengalaman di industri sesuai dengan produk TEFA yang telah ditentukan. Untuk sekolah yang memproduksi pakaian jadi masal guru harus magang di industri garmen yang memiliki produk-produk berskala nasional dan internasional. Untuk SMK yang mengembangkan produk berbasis custome made dapat magang di fashion desainer yang bereputasi nasional dan internasional. Melalui magang ini kompetensi dan budaya kerja industri dapat terinternalisasi kepada guru untuk dapat diajarkan pada siswa

6) Menyelaraskan bahan ajar jobsheet, formulir produksi dan pemeriksaan kualitas untuk proses produksi (dapat memodifikasi/mengadopsi langsung dari industri).

Implementasi TEFA pada prinsispnya adalah mengintegrasikan lingkungan, proses dan standar kerja industri dalam proses pembelajaran di keals/bengkel. Untuk dalam pelaksanaan pembelajran harus mengadopsi standar produk, standar kualitas, standar produksi dan budaya kerja industri tertuang dallam perangkat pembelajaran seperti RPP dan jobsheet yang mengadopsi dari dokumen yang ada di industri.

7) Penataan Bengkel dan peralatan

Untuk melakukan pembenahan bengkel perlu dilakukan Analisis pekerjaan dan alur produksi terkait bahan, alat, waktu, dan layout mesin. Dalam penataan laboratorium dna bengkel juga memperhatikan lingkungan kerja yang aman, nyaman dan sehat dengan penerapan budaya 5R.

8) Menetapkan jadwal pembelajaran

Berdasarkan analisis proses produksi berdasarkan karakteristik produk yang akan dihasilkan dari aspek jumlah, waktu, kualitas, prosedur kerja diperlukan perancangan jadwal yang lebih fleksibel anatara sistem reguler dan sistem blok.

9) Melaksanakan kegiatan pembelajaran

Pelaksanaan pembelajaran TEFA dapat dikembangkan dengan beberpa model model pembelajaran berbasis komptensi, pembelajaran berbasis masalah, pembelalajaran berbasis projek, pembelajran berbasis produksi. Setidaknya dilakukan dengan 3 tahapan sebagai berikut

a) Tahap pembelajaran kompetensi kerja Pada tahap ini peserta didik dilatih dan disiapkan untuk menguasai kompetensi kerja yang diperlukan dalam memproduksi produk yang akan dihasilkan. Langkah lagkah pembelajaran dapat dilakukan dengan mengamati dan menganalisis produk yang akan dibuat, merencanakan kebutuhan tempat, bahan dan alat, memproduksi contoh/sampel produk, mengevaluasi produk dan hasil kerja. Dalam proses ini guru melatih dan membimbing siswa untuk menguasai keterampilan yang diperlukan dalam menghasilkan produk sesuai dengan standar yang ditetapkan dan siswa berlatih dengan mengerjakan produksi sampel produk.

b) Tahap produksi

Pada tahap produksi siswa dapat dibagi/dikelompokkan sesuai deskripsi pekerjaan yang harus dilakukan dan bekerja secara tim untuk melakukan produksi dengan langkah sebagai berikut, Siswa memahami spesifikasi produk yang akan dikerjakanmeliputi desain, standar 
ukuran, standar kualitas, jumlah, waktu, siswa bekerja secara mandiri atau berkelompok memproduksi produk sesuai target dan standar kualitas produksi yang telah ditetapkan, menerapkan budaya K3, guru melakukan pengendalian mutu selama proses produksi, dan guru dan siswa bersama melakukan evaluasi akhir terhadap produk yang telah dihasilkan

c) Pengembangan wirausaha

Pembelajaran TEFA diharapkan juga menumbuhkan keterampilan berwirausaha maka dalam tahap ini siswa dapat dilatih dan diajar

1) Berkreasi untuk mengembangkan dan melakukan inovasi produk

2) Mengembangkan kegiatan pemasaran secara luar jaringan (offline) dan dalam jaringan (online)

3) Mengembangkan komunikasi dan layanan prima kepada pelannggan

4) Membuat rancangan pengembangan bisnis dengan Kanvas model bisnis

5) Evaluasi akhir.

'Berdasarkan panduan pelaksanaan

TEFA Direktorat Pembinaan SMK (2017) setidaknya ada 7 elemen pelaksanaan TEFA yang meliputi:

1) Pengkondisian dan penataan

Laboratorium/Bengkel

Pembenahan ruang praktik dilakukan dengan merenovasi ruangan dan melengkapi peralatan untuk mendukung produksi Produk/Jasa

2) Produk dan jasa yang dihasilkan

Menetapkan produk atau jasa sesuai kompetensi keahlian, potensi sumber daya sekolah dan kerjasama industri. Produk/jasa adalah media untuk pencapaian kompetensi.

3) Model pembelajaran

4) Mengembangkan model pembelajaran berbasis industri dengan mengembangkan perangkat pembelajaran yang disesuaikan dengan standar kerja industri berdasarkan produk dan jasa yang dihasilkann.

5) Sumberdaya manusia

Pengembangan SDM dilakukan dengan mengirimkan magang guru ke industri yang sesuai dengan produk/jasa dalam pelaksanaan TEFA untuk memahami prosedur, kualitas dan budaya kerja industri. Jika memungkinkan siswa dapat juga melakukan kunjungan industri untuk observasi langsung di lapangan/pasar
6) Manajemen

Manajemen TEFA di SMK dilakukan dengan dukungan komitmen manajemen, pembentukan tim, struktur organisasi, rencana/program kerja, deskripsi tugas yang jelas, SOP dan alur kinerja, pengelolaan Administrasi pembelajaran dan keuangan, serta lingkungan pembelajaran yang baik.

7) Hubungan industri

Mengembangkan hubungan industri dan keterlibatan aktif praktisi/industri sebagai satndar, bencmark , mentor, supervisor, lisensi , pemasaran, untuk pelaksanaan TEFA.

8) Informasi produk Info produk dalam katalog cetak dan digital maupun melalui sosialisasi media online maupun offline dan events kegiatan seperti layanan uji coba dan jasa gratis pada saat launching produk atau hari-hari khusus,

\section{PENUTUP}

SMK Tata Busana menjadi salah satu pilar dalam menyediakan SDM di industri fashion. Industri fashion Indonesia saat ini terus tumbuh dengan pesat baik di sektor industri kreatif maupun di industri garmen yang padat karya. Lulusan SMK Tata Busana diharapkan mampu mendukung kebutuhan SDM yang kompeten untuk mengembangkan indsutri fashion agar terus tumbuh menjadai salah satu pilar ekonomi bangsa.Penerapan TEFA di SMK merupakan salah satu upaya untuk meningkatkan link and match dunia pendidikan dan industri untuk mendukung program Making Indonesia 4.0.

Pelaksanaan pembelajaran TEFA setidaknya mencakup 3 komponen utama yaitu penataan laboratorium yang mencerminkan lingkungan kerja industri, Produk/jasa yang layak jual untuk mengantarkan pencapaian kompetens,i dan proses pembelajaran yang mengadopsi dari standar industri. Tahapan pembelajaran dapat dilakukan dalam 3 tahap yaitu pembelajaran kompetensi, produksi dan pengembangan usaha. Penerapan TEFA memerlukan komitmen manajemen SMK dalam memfasilitasi kreasi, produksi, pemasaran dan pengembangan usaha untuk menyiapkan 
lulusan agar memiliki kompetensi yang dibutuhkan di pasar kerja masa depan.

\section{DAFTAR PUSTAKA}

Direktorat Pembinaan SMK Kementerian Pendidikan dan Kebudayaan, 2017, PANDUAN PELAKSANAAN TEACHING FACTORY.

Direktorat Riset dan Pengembangan Ekonomi Kreatif Deputi Riset Edukasi dan Pengembangan Badan Ekonomi Kreatif, 2017, DATA STATISTIK DAN HASIL SURVEI EKONOMI KREATIF KERJASAMA BADAN EKONOMI KREATIF DAN BADAN PUSAT STATISTIK. BEKRAF.

Eberhard Abele, et al , 2015, LEARNING FACTORIES FOR RESEARCH, EDUCATION, AND TRAINING, Procedia CIRP 32 ( 2015 ) $1-6$, The 5th Conference on Learning Factories 2015, ScienceDirect -Elsevier.

Fitrihana, N. (2017). MODEL BISNIS KANVAS UNTUK MENGEMBANGKAN TEACHING FACTORY DI SMK TATA BUSANA GUNA MENDUKUNG TUMBUHNYA INDUSTRI KREATIF. Jurnal Taman Vokasi, 5(2), 212-218.

doi:http://dx.doi.org/10.30738/jtvok.v5i $\underline{2.2526}$

Kementerian Perindutrian Republik Indonesia , 2018. SOSIALISASI MAKING INDONESIA 4.0. 